\title{
DAVID HOSACK AND THE RUTGERS MEDICAL COLLEGE
}

\author{
By Loring B. Priest
}

Most Rutgers men forget that the college ever bad a Medical School, but the bistorians of medicine remember well the troubles of Dr. David Hosack and bis colleagues. The story told bere by Dr. Priest rests on the evidence supplied by the manuscript remains wbich are stored in the Library. The events occurred in the time of the third medical college at Rutgers. The first ran from $I 792$ to I793, and the second from 1812 to 1816 , when Rutgers was still Queen's College. Dr. Priest is bimself a Rutgers graduate of the Class of 1930. His first book, Uncle Sam's Stepchildren, a study of United States Indian policy, is being publisbed by the Rutgers University Press tbis autumn.

$\mathbf{I}$

$\mathrm{N}$ I 826 five outstanding physicians resigned from the staff of the College of Physicians and Surgeons and attempted to establish a medical school in collaboration with Rutgers College. The facts are fully recorded in our medical histories. ${ }^{1}$ But public documents do not reveal fully the intensity of the dispute, which created lasting antagonisms between New York doctors and ended only with the collapse of Rutgers Medical College. In refusing to sanction Rutgers degrees on the ground that local control of education would be jeopardized, the New York legislature only advanced an official excuse for a move which would have been made in any case. ${ }^{2}$ Much more influential than states rights in producing a determination to wreck the school was jealous hatred of the accomplishments of its founders. In the bitter words of personal correspondence, platform tirades, and magazine invective rather than in the refinements of formal reports is to be found the real cause for the failure of Rutgers Medical College after this third beginning.

Dr. David Hosack, head of the new school and widely rec-

${ }^{1}$ Adequate accounts may be found in John C. Dalton, History of the College of Pbysicians and Surgeons, New York, 1888; James J. Walsh, History of Medicine in New York, I9I9; and David D. Demarest, Rutgers (2ueen's) College and Medical Degrees, Trenton, I894.

${ }^{2}$ States rights was definitely eliminated as an issue the following year when the legislature prohibited Geneva College from granting degrees to Rutgers Medical College graduates. It was this action, upheld by New York courts in 1830 , which forced Hosack and his colleagues to abandon their efforts. 
ognized as America's leading physician, ${ }^{3}$ was the center of the storm, and, in fact, he had done much to arouse hostility. Quick-tempered and imperious, he frequently entered controversial discussion with a tactlessness which won few friends. His prominence in the political and cultural life of New York might have been more tolerable if he had been less vain. A colleague, Valentine Mott, might forgive Hosack's insistence that the practice of surgery was unworthy of a gentleman $;^{4}$ but less favorably disposed acquaintances were unwilling to condone his declaration that a deceased friend was the only man he had ever met who approached his abilities. ${ }^{5}$ Yet unreasonable as Hosack was in proclaiming his own merits, the criticism he faced in establishing Rutgers Medical College presented an equally inaccurate picture of the man.

The personal contempt for Hosack, which motivated opponents of Rutgers Medical College, caused them to seize every opportunity to abuse him. Their chief medium was the New York Medical and Pbysical Fournal, inaugurated under Hosack's influence in I 820 but controlled after 1824 by his enemies. ${ }^{6}$ After Rutgers Medical College had opened, each issue of this publication raged at Hosack as vain and deceitful. $\mathrm{He}$ had never received, it was stated, the Edinburgh degree he so proudly claimed. ${ }^{7} \mathrm{He}$ had impetuously resigned a Columbia post with the excuse that it was unworthy of his talents. ${ }^{8} \mathrm{He}$ was sole author of a series of pamphlets misrepresenting American medical development and emphasizing his own importance. ${ }^{9} \mathrm{He}$ had strongly opposed establishment of a new medical school in New York in 1824 only to found one of his

\footnotetext{
${ }^{3}$ Dr. Hosack's pre-eminent position in these years has been generally recognized even by men critical of his career in other respects (Dalton, op. cit., p. 40; and Valentine Mott, Reminiscences of Medical Teacbers and Teacbing in New York, New York, 1850, p. 8).

"Valentine Mott, Eulogy on tbe late Dr. Fobn W. Francis, New York, 186I, p. 11 .

${ }^{5}$ Hosack referred to the departed as "the only man with whom, in the whole course of my life, I have come into any sort of collision-whose talents and whose station could for a moment induce me at least to consider him as a rival." (David Hosack, Eulogium on Dr. Post, p. 20, quoted in a satirical broadside against Rutgers Medical College to be found in the Rutgers University Library.)

- Hosack's close friend, Dr. John W. Francis, announced in March 1825 that his connection with the Fournal had ceased (New York Medical and Pbysical Fournal, IV, March 1825, p. I44). The new editor, Dr. John B. Beck, was as hostile to Hosack as Francis had been friendly. ${ }^{7}$ Ibid., VII (March I 828), footnote, Pp. I 57-I 58. This charge is apparently true. Although Hosack studied in Edinburgh for a year, there is no evidence that he received a degree.

Ibid., VII (December 1828), footnote, p. 6II.

Ibid., VI (December I827), p. 624 .
} 
own two years later. ${ }^{10}$ Such a man, obviously, was not to be trusted. When Hosack was defeated in an effort to win the presidency of the New York county medical society, therefore, his enemies enthusiastically hailed the outcome as a blow to "partizans of Rutgers College."11 Continued success in the campaign against the new school seemed to prove beyond question that all just causes will eventually triumph. So at least believed Dr. J. Augustine Smith, of the College of Physicians and Surgeons, who on the occasion of a colleague's death concluded a long attack upon Hosack by stating:

I acknowledge that by puff and parade, by sounding his own praise and by hiring others to "swell the note," a man may acquire a certain kind of notoriety. This is particularly easy in medicine, from the acknowledged incompetency of the public to judge of medical men. But this mushroomfame never lasts. In the end justice is sure to be done, and mankind, though imposed upon for a time, finally reduce the vain pretender to that obscurity from which he so improperly and frequently so surreptitiously emerged.12

Under such provocation, even a much less irritable man than Hosack must have replied.

Hosack regarded the attacks upon Rutgers Medical College as nothing more than the complaints of jealous rivals. Men, discontented with the prosperity of one with whom they had been unable to maintain successful competition, raked evidence together "from every kennel" to discredit their intellectual superior. ${ }^{13}$ If United States medical progress was to continue without interruption, such culprits must be defeated and Rutgers Medical College must be preserved to train students without interference by political authorities. ${ }^{14}$ Surely the New York legislature would not prescribe geographical limits to knowledge, Hosack wrote his agent in Albany, nor condemn

\footnotetext{
${ }^{10}$ Hosack's long record of opposition to establishment of a second New York medical school was frequently used to discredit his effort to found a school independently following his resignation from the College of Physicians and Surgeons. The case was expressed most fully in An Enquiry into the Present System of Medical Education, by an Observer, Albany, 1830, pp. II-I3.

${ }_{11}$ New York Medical and Pbysical Fournal, VI (June 1827), p. 320.

12 J. Augustine Smith, "An Eulogium on the late Wright Post," in the New York Medical and Pbysical Fournal, VII (September 1828), pp. 435-436.

${ }_{13}$ David Hosack, Inaugural Discourse at the opening of Rutgers Medical College, New York, 1826, p. 35. This explanation of the opposition to Rutgers Medical College occurs again and again in Hosack's description of the crisis which led to the founding of his school.

${ }^{14}$ See especially Remonstrance of Rutgers against the Regents, a communication accompanying a report of March 25, I829 (New York Senate No. 224, April 4, 1829).
} 
the city to existence as a mere marketplace, the home of Goths and vandals. ${ }^{15}$ Toward men whom he believed were destroying the educational opportunities of American youth, he refused to be tolerant. Such men were "tigers . . . ready to convert all to their selfish and savage gratification," Hosack told the first graduating class of the medical college. ${ }^{16}$ Professional gossips bent on reducing abler men to their own level should be given no quarter. ${ }^{17}$ The Doctor turned on his tormentors with such violence in parrying their attacks that he soon was sued for libel. ${ }^{18}$ The charge could not be considered seriously, however, for his critics were equally guilty in their abuse not only of Hosack himself but of all who had the courage to defend him. ${ }^{19}$

Outstanding among innocent victims of the quarrel over Rutgers Medical College was the distinguished physician, James Thacher. Author of excellent catalogues of American medical men and institutions, Thacher published his exhaustive American Medical Biograpby in I828. This book, in the preparation of which Hosack had aided, included a brief but extremely favorable account of the origin and accomplishments of Rutgers Medical College. ${ }^{20}$ Such a report did not escape the wrath of Hosack's opponents. In a lengthy review, at least half of which was devoted to vilification, Dr. Beck declared:

We had understood ... that the events of the present day in medical politics, were to remain unnoticed. Dr. Thacher has, however, seen fit in several places to take the stand of a partisan - to deliver decisive and sweeping opinions on subjects at least admitting of discussion, and to judge concerning them in a manner certainly not according with the views of many of those, who, before this, have felt for him nothing but esteem and respect. ${ }^{21}$

${ }^{15}$ David Hosack to Joseph Blount, February 25, 1827 (MS. in Rutgers University Library).

16 David Hosack to a Committee of Students, April 5, 1826, in David Hosack, Observations on the Medical Cbaracter, New York, 1826, p. 4.

${ }^{17}$ Ibid., p. 27.

${ }^{18}$ Hosack wrote shortly after his graduation address of $\mathrm{I} 826$, "I find I am prosecuted. Is it not possible to arrest their proceedings?" (David Hosack to Joseph Blount, February I 9 , I $827 M S$. in RUL)

${ }^{19}$ A group of New York physicians who backed Hosack were forced to deny that they were "refuse practitioners of other cities, whose cupidity, avarice and immoral conduct" had driven them to New York "as an ample theatre to try some new adventure." (Proceedings of a Meeting of Pbysicians and Surgeons, Held at tbe Sbakspeare Hotel, New York, I3tb February, 1830.)

${ }_{20}$ James Thacher, American Medical Biograpby, Boston, 1828, pp. vi, 55-56, 62-64. See also the favorable account in James Hardie, The Description of the City of New-York, 1827, pp. 278-280. This account may also have been influenced by Hosack, since the publishers reported that the late James Hardie had completed the volume only to p. 276 (ibid., p. 347).

${ }^{21}$ New York Medical and Pbysical Fournal, VII (September I828), p. 406. 
Yet Thacher was not solely to blame that part of the account under New York was "pure fiction," that much of the remainder was "a downright insult," and that everything really creditable was purposely omitted. ${ }^{22}$ "Dr. Thacher never wrote this part of his history," the reviewer informed his readers, "and he has only fallen into this injustice by a misplaced confidence in . . . deceivers, who to bolster up a windy reputation, have been willing to sacrifice the character of this book, as well as that of its venerable author." ${ }^{23}$ Friendship with Hosack and interest in the future of Rutgers Medical College had exposed Thacher to public abuse and by throwing doubt upon his impartiality now threatened the success of his book. Dr. Hosack, however, was inclined to belittle the effectiveness of Beck's attack. Writing on New Year's day in I 829 that Rutgers Medical College was "far exceeding all expectations," Hosack endeavored to strengthen Thatcher's confidence in the following note:

Your book is highly esteemed. Dr. Beck has reviewed it with his accustomed malevolence of spirit both natural and acquired, but his pages are read by few and even that number is daily diminishing, insomuch that the publisher and owner must discontinue the work. The subscribers are not sufficient to meet the expense. You therefore have nothing to apprehend, and let me add that there is not a pupil who leaves our school that is not duly impressed with the important services you have rendered the profession in your various publications. ${ }^{24}$

In so expressing his gratitude, Hosack paid just tribute to Thacher, who had suffered because of friendship for him.

Similar thanks were also due the trustees of Rutgers College, who by consenting to grant degrees to Hosack's students likewise exposed themselves to attack. Physicians who wished to maintain New York medical instruction in the hands of a single school already had good reason to dislike Rutgers. As Queen's College, the institution had permitted Dr. Nicholas Romayne to award degrees both in 1792 and $\mathrm{I} 793$ and from I8I2 to $1816{ }^{25}$ Now that Dr. Hosack had been granted a similar privilege, partisans of the College of Physicians condemned the New

22 Ibid., p. $4^{\mathrm{I} 4}$.

${ }^{23}$ Ibid., Pp. 4I4, $4^{\mathrm{I} 6}$.

${ }^{24}$ David Hosack to James Thacher, January I, I 829 (MS. in RUL).

${ }^{26}$ The details of relations between Romayne and Queen's College are excellently described in the early portions of Dr. Demarest's article (op. cit.). 
Jersey college as a chronic troublemaker. But while Rutgers trustees were represented as over-desirous of receiving ten dollars from each graduate of Hosack's school, ${ }^{26}$ a more fundamental explanation seemed necessary. In the opinion of Hosack and his colleagues, Rutgers acted from a desire to promote education in this country and to resist monopoly. ${ }^{27}$ Search for a selfish motive, which might be employed to counteract such praise, was not particularly successful. In a long and bitter tirade accusing Rutgers of responsibility for the backwardness of American medicine, however, President Manley of the New York Medical Society hinted that intercollegiate rivalry might explain why Rutgers had frequently interfered. Not only the original grant of rights, to which he immediately referred, but the later episodes also were in mind when Manley declared:

What the motives were, of the trustees of Queen's College, in thus unceremoniously interfering with the academic concerns of this State, we are left to conjecture. It had always been a sickly institution, and stood in need, no doubt, of all the support it could obtain to enable it to compete with its sister at Princeton. ${ }^{28}$

But if by any chance Rutgers trustees hoped to preserve the contest with Princeton through annual graduation fees from a New York medical school, they were bitterly disappointed. When the New York legislature refused to allow Rutgers to grant degrees in 1827 , the college's connection with Hosack's institution ended; and three years later Rutgers Medical College itself succumbed, the victim of an implacable hatred of Hosack and his friends.

${ }^{26}$ Transactions of the New York Medical Society, 1807-183I, Albany, 1868, p. 399; and An Enquiry (op. cit.), p. 9, e.g.

${ }^{27}$ See especially the speech of Dr. Macneven in David Hosack, Inaugural Discourse, pp. 168-r69.

${ }^{28}$ Transactions of the New York Medical Society, p. 397. 